\title{
LAS RELACIONES ENTRE EMPLEO E INCLUSIÓN SOCIAL: TRANSFORMACIONES Y RETOS DE FUTURO
}

\author{
The relationship between employment and social inclusion: \\ changes and challenges for the future
}

El presente número 43 de LAN HARREMANAK es producto de la confluencia de dos circunstancias radicalmente diferentes pero inspiradoras ambas: de un lado, es producto de la colaboración de la revista y de la Facultad de Relaciones Laborales y Trabajo Social con el Grupo de Investigación CIVERSITY: Ciudad y Diversidad, colaboración que se encuadra en el ámbito de un proyecto de investigación financiado por el Ministerio de Economía y Competitividad y del Fondo Europeo de Desarrollo Regional [CSO2015-70085-R. MINECOFEDER] desarrollado por el mencionado Grupo de Investigación y que permitirá la publicación y estructuración de este número monográfico, tanto en la manera digital habitual como en formato impreso. En este sentido, el Consejo de Redacción de LAN HARREMANAK quiere agradecer su disposición y trabajo a Amaia Izaola y a Imanol Zubero, sin los cuales esta colaboración hubiera sido imposible. La introducción del número actual en su versión ultimada correrá a cargo, precisamente, de CIVERSITY.

La segunda circunstancia es, ciertamente, más desafortunada. Durante los últimos meses la pandemia generada por el virus SARS-CoV-2 y el confinamiento correspondiente han incidido sensiblemente en la práctica totalidad de las facetas de nuestra experiencia vital cotidiana. La acusada intensidad y amplitud del fenómeno, desconocida para la mayoría de las generaciones actuales, se explica en buena medida por el cruce de relaciones entre lo sanitario y lo laboral. En efecto, las medida socio-sanitarias ante la expansión enfermedad Covid-19 y sus efectos han impactado en el mundo del trabajo-empleo de forma singular $y$, al hacerlo, el ámbito de lo laboral ha devuelto amplificado, enriquecido y pro- 
longado ese impacto en nuestras vidas cotidianas. El trabajo es una faceta vital, sí, pero además dotada de una especial capacidad de incidir en el resto de aspectos que componen la experiencia cotidiana de las personas, los grupos, las organizaciones y las instituciones sociales.

Como no podía ser menos, esta situación ha afectado también al número 43 LAN HARREMANAK y lo ha hecho en un doble sentido: de un lado ha complicado su elaboración, como resultado que es de un proceso de trabajo, igual que cualquier otro bien o servicio que se produce socialmente; pero, de otro lado, ha supuesto también un importante objeto de reflexión y estudio para algunos de los aportes que tenemos la satisfacción de compartir.

Todos los artículos que proponemos a las lectoras y lectores, como es habitual han obtenido la aprobación de sus evaluadoras y evaluadores externas correspondientes, por decisión mayoritaria, y con un mínimo de dos evaluaciones positivas. Queremos mostrar nuestro mayor agradecimiento al amplio elenco de personas evaluadoras por su gran desempeño, realizado además en tiempos de sobrecarga de trabajo y problemas de conciliación en muchos casos. Sin sus consejos, correcciones, y valoraciones el número 43 no hubiera sido posible con la presente calidad. También nuestro agradecimiento las autoras y autores que han querido publicar sus trabajos en LAN HARREMANAK.

Un cordial saludo.

\section{Luis Belaustegi \\ LAN HARREMANAK - Revista de Relaciones Laborales \\ Director}

30 de junio de 2020 


\title{
ENPLEGUA ETA GIZARTERATZEAREN ARTEKO HARREMANAK: ERALDAKETAK ETA ETORKIZUNEKO ERRONKAK
}

\begin{abstract}
LAN HARREMANAK aldizkariaren 43. zenbaki hau bi zirkunstantzia erabat desberdin baina inspiratzaileak bateratzearen emaitza da: alde batetik, aldizkariak eta Lan Harreman eta Gizarte Langintza Fakultateak CIVERSITY: hiria eta Aniztasuna Ikerketa Taldearekin duten lankidetzaren emaitza da. Lankidetza hori Ekonomia eta Lehiakortasun Ministerioak eta Eskualde Garapenerako Europako Funtsak finantzatutako ikerketa-proiektu baten esparruan kokatzen da [CSO2015-Eskualde Garapenerako Europako Funtsa. MINECO-FEDER], ikerketa talde horrek garatu duelarik, eta aukera emango digu ale monografiko hau argitaratzeko eta egituratzeko, bai ohiko modu digitalean, bai inprimatutako formatuan. Ildo horretan, LAN HARREMANAK aldizkariko Erredakzio Kontseiluak eskerrak eman nahi dizkie Amaia Izaolari eta Imanol Zuberori erakutsi duten prestutasunagatik eta lanarengatik, horiek gabe ezinezkoa izango baitzen aipatutako lankidetza. CIVERSITYk hartu du, baita ere, egungo zenbakiaren bertsio burutuari sarrera egitearen hardura.

Bigarren zirkunstantzia, jakina, zoritxarrekoagoa da. Azken hilabeteetan, SARS-CoV-2 birusak sortutako pandemiak eta dagokion konfinamenduak eragin nabarmena izan dute gure eguneroko bizi-esperientziaren ia alderdi guztietan. Fenomenoaren intentsitate eta zabaltasun nabarmena, gaur egungo belaunaldi gehienentzat ezezaguna dena, neurri handi batean osasunaren eta lanaren arteko harremanek azaltzen dute. Hain zuzen ere, Covid-19 gaixotasunaren hedapenaren aurreko neurri soziosanitarioek eta haren ondorioek eragin berezia izan dute lan-enpleguaren munduan, eta, hori egitean, lanaren esparruak areagotu, aberastu eta luzatu egin du inpaktu hori gure eguneroko bizitzan. Lana bizi-alderdi bat da, bai, baina, gainera, pertsonen, taldeen, erakundeen eta gizarte-erakundeen eguneroko esperientzia osatzen duten gainerako alderdietan eragiteko gaitasun berezia du.
\end{abstract}


Jakina, egoera horrek eragina izan du Lan Harremanak-en 43. zenbakian, eta bi zentzutan egin ere: alde batetik, zenbakia lantzea oztopatu egin du, lanprozesu baten ondorioa baitaz, sozialki ekoizten den beste edozein ondasun edo zerbitzuren antzera; baina, bestetik, zenbaki honetan atsegin handiz partekatzen ditugun ekarpen batzuetarako hausnarketa- eta azterketa-objektu garrantzitsua ere izan da.

Irakurleei proposatzen dizkiegun artikulu guztiek, ohi bezala, kanpoko ebaluatzaileen onespena jaso dute, gehiengoaren erabakiz, eta gutxienez bi ebaluazio positibo izanik. Gure eskerrik beroenak eman nahi dizkiegu ebaluatzaileen zerrenda zabalari, lan-karga handiko garaietan eta, kasu askotan, lana eta familia bateratzeko arazoetan murgilduta egindako lan handiagatik. Haien aholku, zuzenketa eta baloraziorik gabe, 43 zenbakia ez zatekeen posible izango kalitate honekin. Gure esker ona, halaber, beren lanak LAN HARREMANAKen argitaratu nahi izan dituzten egileei.

Agur bero bat.

$$
\begin{array}{r}
\text { Luis Belaustegi } \\
\text { LAN HARREMANAK - Revista de Relaciones Laborales } \\
\text { Zuzendaria }
\end{array}
$$

2020ko ekainaren 30 